\title{
Recent Advances in Fluorescent Probes for Lipid Droplets
}

\author{
Tkhe Kyong Fam, Andrey S. Klymchenko and Mayeul Collot * $\mathbb{C}$
}

Nanochemistry and Bioimaging Group, Laboratoire de Bioimagerie et Pathologies, CNRS UMR 7021, Université de Strasbourg, Faculté de Pharmacie, 67401 Illkirch, France; tkhe-kyong.fam@unistra.fr (T.K.F.); andrey.klymchenko@unistra.fr (A.S.K.)

* Correspondence: mayeul.collot@unistra.fr; Tel.: +33-3-6885-4266

Received: 19 August 2018; Accepted: 14 September 2018; Published: 18 September 2018

check for updates

\begin{abstract}
Lipid droplets (LDs) are organelles that serve as the storage of intracellular neutral lipids. LDs regulate many physiological processes. They recently attracted attention after extensive studies showed their involvement in metabolic disorders and diseases such as obesity, diabetes, and cancer. Therefore, it is of the highest importance to have reliable imaging tools. In this review, we focus on recent advances in the development of selective fluorescent probes for LDs. Their photophysical properties are described, and their advantages and drawbacks in fluorescence imaging are discussed. At last, we review the reported applications using these probes including two-photon excitation, in vivo and tissue imaging, as well as LDs tracking.
\end{abstract}

Keywords: lipid droplets; fluorescent probes; bioimaging

\section{Introduction}

Lipid droplets (LDs) are the lipid storage cellular organelles consisting of a neutral lipid core, mainly containing cholesterol esters and triglycerides [1,2] covered by a phospholipid monolayer shell where a number of associated proteins were recently found (Figure 1). In particular, these include the PAT protein family, with PAT standing for Perilipin (PLIN), Adipocyte differentiation-related protein (ADRP; also called as adipophilin), and TIP47 (tail-interacting protein of $47 \mathrm{kDa}$ ) proteins [3]. LDs can primarily be found not only in the adipose tissue of eukaryotic organisms, but also in other types of cells, since LDs play a very important role in the regulation of cellular lipid metabolism [3].

Recently, LDs received considerable attention as they were shown to be involved in different cellular processes such as membrane formation, trafficking [4], and protein-protein interaction [5]. Moreover, the misregulation of LD functions can cause metabolic disorders such as obesity, fatty liver diseases, diabetes, atherosclerosis, and others [6].

In order to understand its role in different metabolic disorders and get insights on their interactions with other cellular compartments, it is of the highest importance to have reliable imaging tools for LDs. The visualization of cellular LDs can be carried out by label-free imaging techniques, such as conventional transmission light microscopy [7], direct organelle mass spectrometry [8], Raman microscopy [9], and coherent anti-Stokes Raman scattering microscopy [10]. These advanced techniques allowed us to study the biophysics of cellular LDs, but they required complex sample preparations and data analysis. In addition, the mentioned methodologies usually require cells to be fixed or LDs extraction, omitting the possibility of studying the real-time dynamics of LDs in the cellular environment. On the other hand, the fluorescence imaging techniques have proved to be powerful methods to study complex biological processes due to their high sensitivity [11]. It allows precisely imaging the localization, distribution, and biophysical properties of many intracellular compartments such as mitochondria, nucleus, plasma membrane, etc. [12-14]. 
In this review, we focus on recent advances in the field of selective LDs fluorescence imaging. In particular, the advantages and disadvantages of developed fluorescent probes to study LDs biology are discussed, as well as emerging probes that enable LD tracking in cells and tissues.

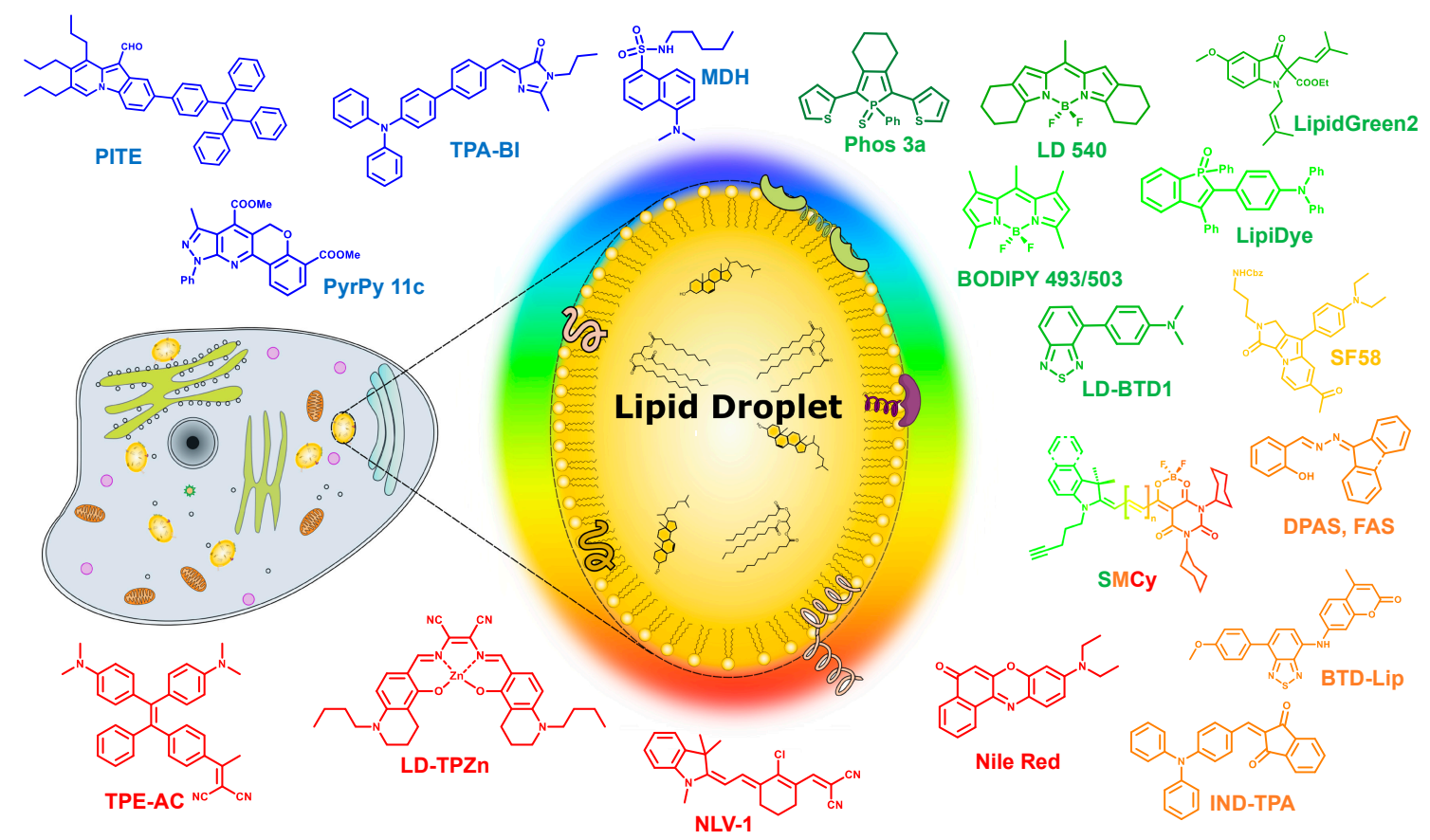

Figure 1. Schematic representation of a lipid droplet and the various multicolor liquid droplets (LDs) probes discussed in this review.

\section{Common Methods and Probes in LDs Fluorescence Bioimaging}

LD biology research is greatly assisted by chemical tools, allowing easy-to-handle manipulations to study intracellular bioprocesses in live cells. These compounds allowed scientists to image and track LDs under both physiological and pathophysiological conditions $[3,15]$. In this part, we will present the immunostaining targets and the commonly used molecular lipophilic dyes to identify the LDs in cells.

\subsection{Fluorescence Immunostaining}

The immunofluorescence staining technique is a golden standard biochemical method to detect target molecules in laboratory practice. The expression of PAT proteins in LDs permits visualizing LDs using the immunofluorescence technique, in particular if adipophilin is targeted, which is usually abundant in LDs [16]. Despite being a powerful and reliable method that is applicable to staining LDs, careful considerations should be taken when immunofluorescence staining is used. Common protocols require the fixation of cells. Methods of fixation can have a dramatic impact on LDs' morphology. In addition, some LD-associated proteins are weakly detected after the permeabilization step [16]. Thus, the detection of cellular LDs is more practical and feasible when fluorescent small molecules are used, as they stain the lipid core of native LDs. Moreover, since immunostaining requires fixation, it does not allow live cell studies and the tracking of LDs.

\subsection{Diazo Dyes}

Sudan III [17] and Oil Red O [18] (Figure 2) are diazo dyes that have been used as LD strains for decades, since they enable visualizing LDs using conventional bright-field (transmitted light) microscopy. Moreover, both dyes emit a red fluorescence, permitting the use of fluorescence microscopy to analyze LDs. The downfall of those dyes is their poor solubility, thus requiring the usage of ethanol 
or isopropanol for staining. Such invasive staining conditions cause the disruption of native LDs and occasional fusion, despite cells being fixed $[19,20]$.<smiles></smiles>

Sudan III<smiles></smiles>

BODIPY 493/503<smiles></smiles>

BODIPY 505/515<smiles>Cc1ccc(C)c(/N=N/c2cc(C)c(/N=N/c3c(O)ccc4ccccc34)cc2C)c1</smiles>

Oil Red 0

Figure 2. Chemical structures of commonly used fluorescent dyes.

\subsection{Nile Red}

Nile Red (Figure 2) is a commercially available fluorogenic dye that is commonly used to stain LDs in cells [21]. Nile Red exhibits solvatochromic properties fluorescing in most organic solvents and a lipidic environment, while its fluorescence is diminished in aqueous media [21]. Even though Nile Red is an easy-to-handle fluorescent LD marker, there are some limitations to be taken into consideration: (i) non-specific labeling of cellular lipid organelles, in particular intracellular membranes, and (ii) Nile red has broad absorption and emission spectra that lead to cross-talk in the red channel (typically: excitation between 530-560 nm), thus making it non-suitable for multicolor imaging with different dyes or fluorescent proteins.

\subsection{BODIPY $493 / 503$}

Another commonly used commercial fluorescent dye is BODIPY 493/503 (Figure 2) [22]. A structurally close analogue of BODIPY 493/503, namely BODIPY 505/515, is also known to stain neutral lipids [22]. Although BODIPY 493/503 rapidly and reliably labels LDs with bright green fluorescence, it possesses limitations. First, it tends to produce a background signal in imaging due to its non-fluorogenic nature. Indeed, we recently showed that BODIPY 493/503 displays a quantitative quantum yield in aqueous media [23]. Then, we also showed that BODIPY 493/503 has limited photostability [23]. At last, BODIPY 493/503 displays a small Stokes shift (the difference between excitation maximum and emission maximum), which can cause cross-talk between the excitation source and the fluorescence emission. However, BODIPYs were shown to be more selective to LDs than Nile Red, and immediately stain LDs due to a better cell permeation [24,25].

Even though Oil Red O, Nile Red, and BODIPY 493/503 proved to be useful chemical tools to visualize LDs, their utility faces the previously mentioned limitations (specificity, cross-talk, photostability, small Stokes shifts, and background noise). Moreover, the analysis should be done with high precautions; appropriate controls are necessary to be performed to discriminate false positive fluorescence signals [19]. Consequently, these limitations led to the development of new LD fluorescent probes. 


\section{Recent Developments in LDs' Selective Fluorescent Probes}

Recent efforts have been made to develop new probes based on various lipophilic fluorophores expanding the available toolbox to probe LDs. In particular, the smart design of probes improved organelle specificity, photophysical properties, cell permeability, cell toxicity, etc. In this review, we tried to compile an exhaustive list of fluorescent probes targeting LDs spanning their fluorescence from blue to near-infrared (NIR) region. For clarity, we grouped the fluorescent probes by their reported emission color in the less polar solvent as followed: blue $\left(\lambda_{\mathrm{em}}<500 \mathrm{~nm}\right)$, green $\left(\lambda_{\mathrm{em}}=500-550 \mathrm{~nm}\right)$, orange $\left(\lambda_{\mathrm{em}}=550-600 \mathrm{~nm}\right)$, and red to NIR $\left(\lambda_{\mathrm{em}}>600 \mathrm{~nm}\right)$.

\subsection{Blue Emitting LD Probes $\left(\lambda_{\text {em }}<500 \mathrm{~nm}\right)$}

The color availability of LD markers provides the flexibility of setting multicolor fluorescence imaging. The gap in the blue region was recently filled by the development of blue-emitting LD probes.

To this end, Yang et al. reported the utility of commercially available fluorophore monodansylpentane (MDH) as a blue marker of LDs (Figure 3) [26]. MDH was challenged to be compatible in multicolor one-photon excitation (1PE) imaging. It was also compatible with two-photon excitation (2PE) imaging using 760-nm excitation.

Inspired by the successful utility of MDH as a blue LD marker, two series of dyes were developed based on dihydrochromenopyrrolopyridine and the -pyrazolopyridine core (Figure 3. PyrPy 10d, PyrPy 11c) as potential blue LD markers [27]. The dyes showed solvatochromic behavior. Bathochromic shifts were observed with an increasing polarity of solvents indicating a greater dipole moment in the excited state in comparison to the ground state of the molecules. This feature proved that the molecules undergo intramolecular charge transfer (ICT) and are associated with positive solvatochromism. It was noted that the introduction of the ester group into the pyridine core improved ICT and cell permeability. Moreover, the introduction of the second ester group dramatically increased selectivity toward LDs.

PITE [28] arose from the combination of pyroindole (PI) and tetraphenylethylene (TE) (Figure 3). PI emits strong green fluorescence in organic solvents, while its fluorescence is quenched in aqueous solution due to poor solubility and aggregation. On the other hand, TE is known to be an aggregation-induced emission (AIE) molecule [29]. Coupling PI and TE resulted in a molecule with new properties. Authors have reported PITE capacity to specifically detect LDs. The absorption spectra of PITE displays two bands at 320 and $420 \mathrm{~nm}$ as contributions of both moieties TE and PI respectively, while it emits at $490 \mathrm{~nm}$ and does not depend on excitation wavelength. Using Saccharomyces cerevisiae (as the yeast cell model) and HeLa cells (as the mammalian cell model), Sk et al. showed the compatibility of PITE as a blue fluorescent LD probe [28].<smiles>CCCCCNS(=O)(=O)c1cccc2c(N(C)C)cccc12</smiles>

MDH<smiles>CC(=O)c1c2c(nc3c1c(C)nn3-c1ccccc1)-c1ccccc1OC2</smiles>

PyrPy 10d<smiles>CN(C)c1ccc(C(=C(c2ccccc2)c2ccc(C=O)cc2)c2ccc(N(C)C)cc2)cc1</smiles><smiles>CC(=O)c1cccc2c1OCc1c-2nc2c(c(C)nn2-c2ccccc2)c1C(C)=O</smiles>

PyrPy 11c

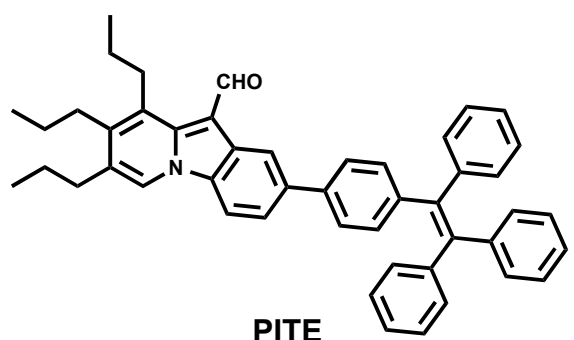

PITE<smiles>CCCN1C(=O)/C(=C/c2ccc(-c3ccc(N(c4ccccc4)c4ccccc4)cc3)cc2)N=C1C</smiles>

Figure 3. Chemical structures of blue emitting LD probes. 
Other blue AIEgens that are specific for LDs were developed in the Tang group and named TPE-AmAl [30] and TPA-BI (Figure 3) [31]. TPE-AmAl consists of TE as an AIE-unit emitting in the blue region, the alkylamino group as an electron donor, and carbonyl as an electronacceptor to promote the intramolecular charge transfer (ICT) process. Although TPE-AmAl emits at $610 \mathrm{~nm}$ as aggregated form in aqueous conditions, it exhibits blue emission once in cellular LDs. This difference is attributed to the non-polar environment of LDs and solvatochoromic properties of the dye (blue shift in less polar solvents). The LD-targeting property was confirmed by costaining with Nile Red [30]. TPA-BI bears triphenylamine (TPA) moiety as an electron donor and as a common unit for enhancing two-photon absorption (2PA) properties. On the other hand, benzylidene imidazolone (BI) was shown to be AIE-active. TPA-BI exhibited solvatochromic properties emitting from blue to red when the solvent changed from n-hexane $(447 \mathrm{~nm})$ to acetonitrile $(619 \mathrm{~nm})$, which was nearly covering the full visible spectrum. Authors have shown that TPA-BI can perform both in 1PE and 2PE fluorescence cell imaging. In 1PE imaging, TPA-BI also showed an excellent resistance to photobleaching in addition to high LD specificity. Since TPA-BI shows a 2 PA cross-section $\left(\delta_{2 \mathrm{PA}}\right)$ value of up to $213 \mathrm{GM}$ at $840 \mathrm{~nm}$, the evaluation of its compatibility in $2 \mathrm{PE}$ cell imaging was also conducted. The result showed that TPA-BI performed better in 2PE in comparison to 1PE imaging.

Even though reported blue probes successfully stained intracellular LDs, they share common limitations such as limited brightness (due to low $\varepsilon$ ), a high background signal due to cell autofluorescence, and the considerable phototoxicity of ultraviolet/violet excitation.

\subsection{Green Emitting LD Probes $\left(\lambda_{e m}=500-550 \mathrm{~nm}\right)$}

Anh et al. developed green-emitting LDs probes LipidGreen $\left(\lambda_{\text {ex }} / \mathrm{em}\right.$ in PBS $\left.=485 / 515 \mathrm{~nm}\right)$ and LipidGreen2 $\left(\lambda_{\text {ex } / \mathrm{em}}\right.$ in PBS $\left.=456 / 534 \mathrm{~nm}\right)$ (Figure 4) [32,33]. Both dyes were proved to stain LDs in co-localization experiments with LD-associated protein (Periplin) and red emitting LipidTOX ${ }^{\mathrm{TM}}$ (neutral lipid).

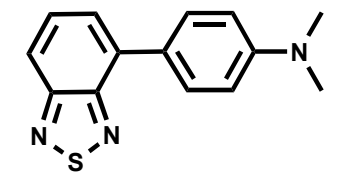

LD-BTD1

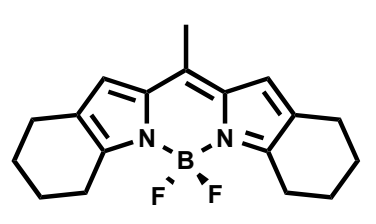

LD540

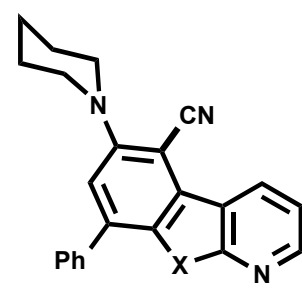

AF8 $=\mathrm{R}=\mathrm{CH}_{2}$ AFN: $\mathrm{R}=\mathrm{CO}$ AD10: $\mathrm{R}=\mathrm{CHOH}$

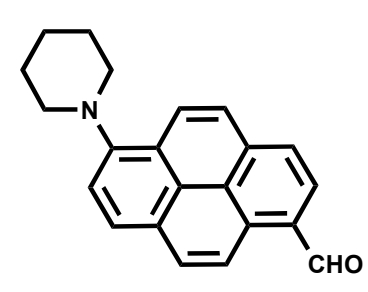

PA<smiles>[R]C([R])=CCN1c2ccc(OC)cc2C(=O)C1(CC=C([R])[R])OCC</smiles>

LipidGreen: $\mathrm{R}=\mathrm{H}$ LipidGreen2: $\mathrm{R}=\mathrm{Me}$

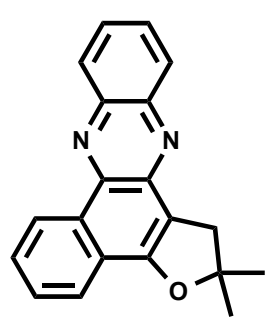

P1

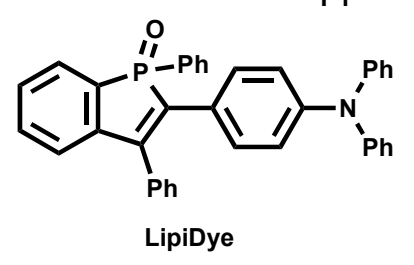

Figure 4. Chemical structures of green-emitting LD probes. 
A BODIPY-based lipophilic dye LD540 was introduced for LD imaging (Figure 4) [34]. In sunflower oil, LD540 fluoresced at $545 \mathrm{~nm}$. Well-defined images were obtained when LDs were costained with LD540 and LD-protein ancient ubiquitous protein 1 (AUP1). It is noteworthy that, unlike BODIPY 493/503 and due to its red-shifted emission wavelength, LD540 is prone to cause cross-talk between green and red fluorescence channels in microscopy.

Another family of fluorogenic dyes that have been reported to stain LDs are based on azafluorenes (AF8, AF10) and azafluorenones (AFN) (Figure 4) [35]. In DMSO, AF8 and AF10 showed absorption maxima at $375 \mathrm{~nm}$ and $352 \mathrm{~nm}$, respectively, and fluorescence maxima at $479 \mathrm{~nm}$ and $477 \mathrm{~nm}$, respectively. Interestingly, in DMSO, AFN exhibited absorption maximum at $432 \mathrm{~nm}$ and a fluorescence maximum at $592 \mathrm{~nm}$ with a Stokes shift of $160 \mathrm{~nm}$. AF8 and AF10 did not exhibit solvatochromism, while AFN showed solvatochromic shifts, increasing polarity from cyclohexane $\left(\lambda_{\mathrm{em}}=510 \mathrm{~nm}\right)$ to $\operatorname{DMSO}\left(\lambda_{\mathrm{em}}=592 \mathrm{~nm}\right)$. The solvatochromic nature of AFN clearly indicates that the molecule undergoes ICT process. Even though AF8 and AF10 showed interesting photophysical properties, only AFN was able to permeate cells and nicely co-localized with Nile Red, showing its specificity to LDs [35].

A family of two-photon excitable naphthalene-based LD probes abbreviated as NAP AIEgens (NAP-Ph, NAP-Br, NAP-CF 3 , and NAP-Py, as shown in Figure 4) was recently introduced [36]. AIEgens NAP probes have been reported to fluoresce at $523-540 \mathrm{~nm}$ in an aggregated state in aqueous solution. The NAP AIEgens exhibited a large Stokes shift $(>110 \mathrm{~nm})$ and good $2 \mathrm{PA}$ cross-section $\left(\delta_{2 \mathrm{PA}}\right)$ (45-100 GM at $860 \mathrm{~nm}$ ), and were thus compatible for 2PE fluorescence live cell and tissue imaging. The ability to specifically stain LDs at very low concentrations $(50 \mathrm{nM})$ within a short time $(\sim 15 \mathrm{~min}$ incubation) makes NAP probes very attractive to use in the LDs' cell and tissue imaging by the bot $1 \mathrm{PE}$ and 2PE fluorescence microscopy.

Recently, Appelqvist et al. introduced a new green LD selective emitter based on a benzothiadiazole (BTD) fluorophore named LD-BTD1 (Figure 4) [37]. BTD was cross-coupled to electron-donating dimethylaminophenyl, resulting in a push-pull fluorophore. In hexane, LD-BTD1 exhibits an absorption maximum at $420 \mathrm{~nm}\left(\varepsilon=7100 \mathrm{M}^{-1} \mathrm{~cm}^{-1}\right)$ combined with a fluorescence maximum at $511 \mathrm{~nm}$. LD-BTD1 exhibits an impressive solvatochromic shift with increasing solvent polarity from hexane $\left(\lambda_{\mathrm{em}} \max =511 \mathrm{~nm}\right)$ to DMSO $\left(\lambda_{\mathrm{em}} \max =759 \mathrm{~nm}\right)$. Since the excitation and emission spectra of LD-BTD1 overlap with Nile Red due to its broad peaks, it was challenging to proceed with co-localization experiments in a fluorescence imaging experiment.

A polarity-sensitive benzophosphole oxide-based fluorophore was recently developed as an LD marker under commercial name LipiDye (Figure 4) [38,39]. In toluene, it absorbed at $415 \mathrm{~nm}$ and emitted at $528 \mathrm{~nm}$, as the ICT fluorophore LipiDye exhibited solvatochromic properties. Interestingly, once LipiDye stained LDs, its emission maximum was between $521-530 \mathrm{~nm}$. LipiDye also labeled other cellular compartments, but with a red-shifted emission $\left(\lambda_{\mathrm{em}}=556-565 \mathrm{~nm}\right)$. Due to these spectral differences, it was possible to obtain deconvoluted images to discriminate the hydrophobic environment of LDs from other cellular domains.

A similar approach was employed by Niko et al. using a push-pull pyrene probe PA (Figure 4) [40]. This dye features absorption around $430 \mathrm{~nm}$, with a good extinction coefficient in apolar media $\left(\varepsilon=25,000 \mathrm{M}^{-1} \mathrm{~cm}^{-1}\right)$, a quantum yield close to unity, and emission ranging between $480-600 \mathrm{~nm}$ as a function of solvent polarity. Its cell permeability enabled the efficient labeling of different lipid structures inside the cells, showing the brightest signal from LDs. Due to the strong solvatochromism of PA, lipid droplets were clearly distinguished by their characteristic emission color, using fluorescence ratiometric imaging that was obtained as a ratio of red channel $>550 \mathrm{~nm}$ to green channel $<550 \mathrm{~nm}$. In this case, LDs appeared as the most apolar intracellular lipid structures.

A series of non-fused pyridyl and thienyl-substituted phospholes was proposed as alternative green LD stains (Phos, as shown in Figure 4) [41]. It was shown that the introduction of thienyl groups to the phosphole caused shifts to the red region both in excitation and emission spectra compared to pyridyl groups. In DMSO, Phos $2 \mathrm{~b}$ and Phos $3 b$ exhibited excitation maxima at $377 \mathrm{~nm}$ and $374 \mathrm{~nm}$ and emission maxima at $554 \mathrm{~nm}$ and $550 \mathrm{~nm}$, whereas Phos 2a and Phos 3a displayed excitation maxima 
at longer wavelengths, $439 \mathrm{~nm}$ and $429 \mathrm{~nm}$, and emission maxima at shorter wavelengths, $470 \mathrm{~nm}$ and $512 \mathrm{~nm}$, respectively. It was also shown that thienyl-derived phospholes (Phos 2a and Phos 3a) outperformed the pyridyl-derivatives in fluorescence LD cell staining.

Exploiting natural products as intermediates, Moliner et al. designed the phenazine P1 (Figure 4) as an LD-specific probe [42]. P1 was reported to be environment-sensitive, and could report viscosity. In dioxane, P1 absorbed at $428 \mathrm{~nm}$ and fluoresced at $500 \mathrm{~nm}$, while it formed weakly emissive aggregates in water. P1 co-localized with Nile Red in HeLa cells.

\subsection{Orange Emitting LD Probes $\left(550 \mathrm{~nm}<\lambda_{\text {em }}<600 \mathrm{~nm}\right.$ )}

A series of fluorogenic-dyes based on Seoul-Fluor (SF) core was reported to target cellular LDs (Figure 5) $[43,44]$. By introducing the electron-donating diethyl amino group to the SF core, the molecule was tuned to be fluorogenic, undergoing an ICT process. As consequence, a promising candidate to probe LDs was found to be SF44. The latter fluoresces in a solvatochromic manner, spanning its emission from $561 \mathrm{~nm}$ to $624 \mathrm{~nm}$ (from diethyl ether to acetonitrile). The authors confirmed that SF44 indeed stains LDs by immunostaining LD-associated membrane proteins-adipose differentiation-related protein (ADRP) and perilipin-in the differentiated 3T3-L1 cells and by co-localization experiments using Nile Red [43]. A further rational design to increase the lipophilicity of the molecule resulted in the discovery of the promising candidate SF58 [44]. The improved analogue was tested together with SF44 to probe the LDs in microalgae [44].

Tang et al. recently introduced FAS and DPAS as AIEgens reporting LDs in cells (Figure 5) [45]. They underwent an excited-state intramolecular proton transfer (ESIPT) process, giving large Stokes shift and enhanced orange and yellow emissions due to their keto forms' fluorescence in the aggregated form. FAS and DPAS showed two emission peaks in solutions. Emission from the short-wavelength region corresponds to enol forms of the molecules, while long-wavelength emission is accredited to keto forms $\left(\lambda_{\mathrm{em}}=430 / 600 \mathrm{~nm}\right.$ for FAS; $\lambda_{\mathrm{em}}=425 / 550 \mathrm{~nm}$ for DPAS). FAS and DPAS were nicely co-localized with BODIPY 493/503, proving their LD targeting.<smiles>O=C1C(=Cc2ccc(N(c3ccccc3)c3ccccc3)cc2)C(=O)c2ccccc21</smiles><smiles>[R]N1Cc2c(-c3ccc(N(CC)CC)cc3)c3cc(C(C)=O)ccn3c2C1=O</smiles>

SF44: $\mathrm{R}=(\mathrm{CH} 2)_{2}-\mathrm{NHBoC}$

SF58: $\mathrm{R}=(\mathrm{CH} 2)_{3}-\mathrm{NHCBZ}$<smiles>Oc1ccccc1/C=N/N=C1c2ccccc2-c2ccccc21</smiles>

DPAS, FAS<smiles>COc1ccc(O)c(-c2nc3ccccc3s2)c1</smiles>

BZT 3a, 4a

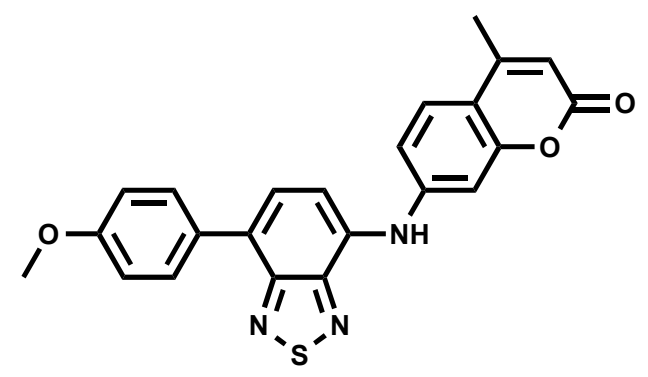

BTD-Lip

Figure 5. Chemical structures of orange-emitting LD probes.

The previously mentioned green-emitting BTD fluorophore was finely tuned into a BTD-coumarin hybrid resulted to discovery of new red-emitting probe, BTD-Lip (Figure 5), for LDs imaging [46]. 
BTD-Lip consists of BTD bearing a coumarin moiety in order to extend the $\pi$-conjugation. BTD is known to be a good electron acceptor; therefore, the p-methoxyphenyl group was linked to BTD as an electron donor to facilitate the ICT process in an excited state. ICT molecule BTD-Lip fluorescence is solvent-dependent, ranging from $585 \mathrm{~nm}$ to $643 \mathrm{~nm}$ (from hexane to DMSO). BTD-Lip can mark LDs in Caco-2 cells, together with BODIPY 493/503. Interestingly, BTD-Lip can also report LDs in worms (Caenorhabditis elegans) [46]. It is important to note that BTD-Lip displays broad emission bands and is prone to cross-talk in imaging.

Inspired by the interesting properties of blue LDs probe TPA-BI (Figure 3) [31], Tang et al. attempted to tune the spectral properties of the molecule by changing the electron-accepting moiety from benzylidene imidazolone to indane-1,3-dione, resulting in a new orange-emitting IND-TPA (Figure 5) [47]. In THF, IND-TPA absorbed at $478 \mathrm{~nm}$ and emitted at $594 \mathrm{~nm}$. IND-TPA displayed atypical AIE behavior: increasing water fraction up to $70 \%$ in THF/water solution resulted in a 13.8-fold florescence intensity drop, but the further addition of water up to $90 \%$ led to a 20.4-fold fluorescence increase. The authors explained that the drop of IND-TPA fluorescence is caused by a twisted intramolecular charge transfer (TICT) effect [48], while the further fluorescence enhancement is credited to aggregation, which caused poor solubility in the water [47]. The co-localization of IND-TPA with standard LD marker BODIPY 493/503 proved the probe specificity. Unlike TPA-BI, IND-TPA gave high signal-to-background ratios. IND-TPA showed a moderate two-photon absorption cross-section of $119 \mathrm{GM}$ upon excitation at $920 \mathrm{~nm}$.

The first example of the photoactivatable AIE probe for LD imaging was recently reported by the same group (BZT 3a Figure 5) [49]. 2-(2-hydroxyphenyl)-benzothiazoline (BZT 3a) can be generated in situ from its disulfide precursor. Such a synthetic route simplified the availability of the LD probe and made it easy to use. BZT 3a underwent photooxidation under illumination at $365 \mathrm{~nm}$ to generate an oxidized form of BZT 4a. BZT 4a showed an emission peak at $570 \mathrm{~nm}$ in the solid state, while it was absorbed at $365 \mathrm{~nm}$. Further investigations showed that in cells, BZT 3a co-localized with BODIPY 493/503. Interestingly, the photoactivation of BZT 3a could occur under two-photon illumination at $780 \mathrm{~nm}$.

Despite the limited brightness compared to commercial BODIPY 493/503, the green and orange LD markers mentioned above were shown to be chemically accessible, cell permeable, and organelle-specific. In addition, some probes have large Stokes shifts, and are two-photon excitable. On the other hand, their broad absorption and emission spectra can lead to fluorescence cross-talk in the red channel, making the utility of those dyes challenging in multicolor fluorescence imaging.

\subsection{Red to Near-Infrared Emitting LD Probes $\left(\lambda_{e m}>600 \mathrm{~nm}\right)$}

Fluorescent dyes operating in the red region are in high demand due to their compatibility with the widely used eGFP protein labeling and with biomedical diagnostics techniques. The predominant advantages of red fluorophores are: (i) low background signal from the autofluorescence of biological samples, (ii) efficient excitation of dyes in thicker tissue samples, and (iii) reduced light scattering.

A red-emitting LD probe was proposed based on a luminescent $\mathrm{Zn}$ (II) complex with a salen ligand named LD-TPZn (Figure 6) [50]. In DMSO, LD-TPZn showed a sharp absorption band centered at $390 \mathrm{~nm}$ with a shoulder at $440 \mathrm{~nm}$ assigned to $\pi-\pi^{*}$ transition, and a low-energy band centered at $599 \mathrm{~nm}$. It displayed an intense red emission at $637 \mathrm{~nm}$ and a quantum yield of 0.44. LD-TPZn displayed fluorogenic behavior, since it formed non-emissive aggregates in PBS, while there was fivefold fluorescence increase in oil-in-water emulsion. LD-TPZn was proved to stain LDs in cells by co-localization with BODIPY 493/503 and immunolabeled LD-associated protein periliplin-1 in cells. LD-TPZn was reported to undergo endocytic cellular uptake, which is an energy-dependent process [50]. The authors claimed that this property prevents non-specific interaction with other cell organelles, thus reducing background fluorescence. LD-TPZn exhibited a two-photon absorption cross-section ( $\delta$ ) of ca. $110 \mathrm{GM}$ at $880 \mathrm{~nm}$, and was used to image LDs in adipose tissue. 
<smiles>CCCCN1CCCc2c1ccc1c2O[C@]23Oc4c(ccc5c4CCCN5CCC)C=CN2C(C#N)=C(C#N)N=C13</smiles>

LD-TPZn<smiles>CC(C)=C(C)c1ccc(C(=C(c2ccccc2)c2ccc(N(C)C)cc2)c2ccc(N(C)C)cc2)cc1</smiles>

TPE-AC<smiles>CN1/C(=C/C=C2\CCCC(C=C(C#N)C#N)=C2Cl)C(C)(C)c2ccccc21</smiles>

NLV-1<smiles></smiles>

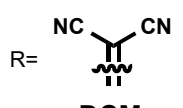<smiles>[Mg][Mg][Mg]</smiles>

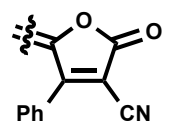<smiles>CC1=CC(=C(C)C#N)CC(C)(C)C1</smiles><smiles>[R]c1nc(N(c2ccccc2)c2ccccc2)c2c(c1C#N)C(=O)c1ccccc1-2</smiles>

DCFu

PhotoAFN 2a-c

$\mathrm{R}=\mathrm{NH}_{2}, \mathrm{NEt}_{2}$, Morpholine

\section{CN}

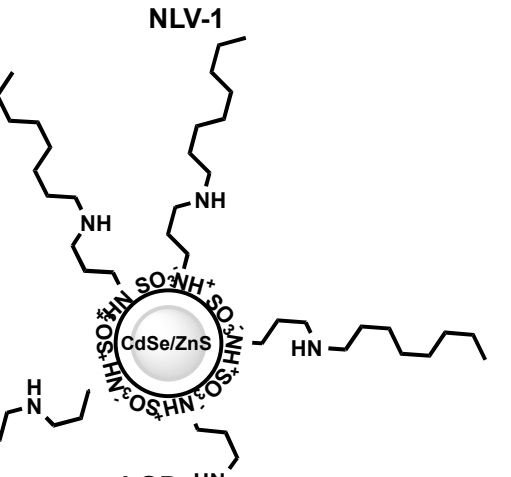

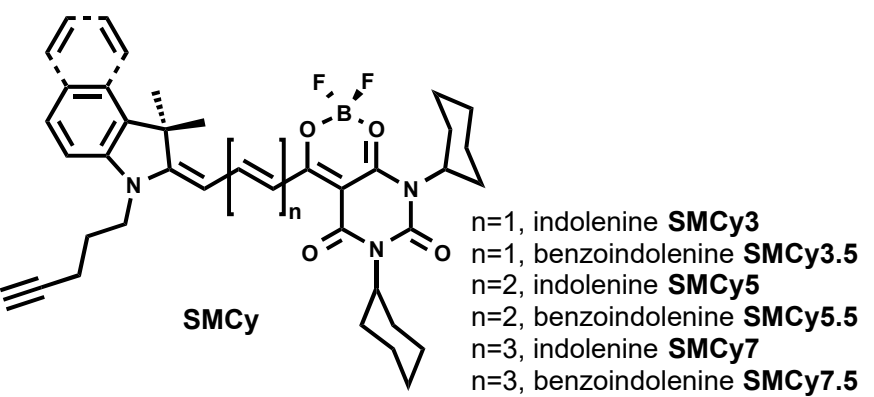

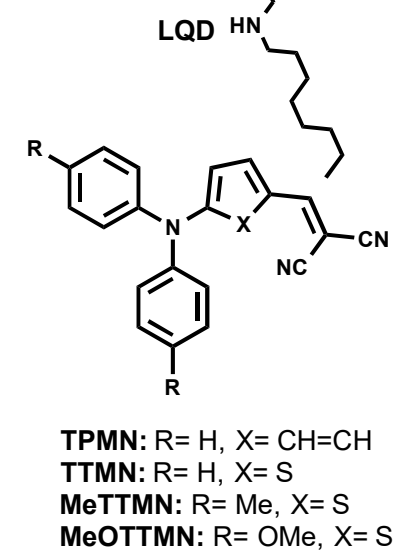

Figure 6. Chemical structures of red-emitting LD probes.

Recently, LQD (Figure 6) was reported as a quantum dot-based fluorescent probe that is selective for LDs [51]. LQD consisted of a red-emitting CdSe quantum dot core capped with a ZnS shell, and covered with polyacrylate coated with octyamine tails. LQD in colloidal solution showed a narrow emission peak at $\sim 600 \mathrm{~nm}$. As a quantum dot, LQD has a wide excitation window; thus, blue excitation was used for the imaging of LDs. LQD entered cell via lipid-raft endocytosis and co-localized with Nile Red. The lipid-raft endocytosis mechanism of LQD uptake minimized its trafficking to the endosome/lysosome. As the authors mentioned, the designed probe can be challenging to use in vivo, since they can accumulate in organs due to the larger size compared to the required size for the clearance.

The exploration of 2-azafluorenone core by Tang et al. resulted in the development of the photoactivatable LD-specific probes [52]. The probes are based on dihydro-2-azafluorenones that could undergo photooxidative raction to form AIEgens 2-azafluorenones (PhotoAFN 2a-c, as shown in Figure 6). They spanned their maximum fluorescence from $610 \mathrm{~nm}$ to $624 \mathrm{~nm}$ in THF solution, and from $571 \mathrm{~nm}$ to $620 \mathrm{~nm}$ in a solid state. As TICT molecules, PhotoAFN 2a-c exhibited solvatochomic properties (blue shift with the decrease of solvent polarity). As expected, in LDs, the probes emitted closer to the orange region of the wavelength. The photoactivation property allowed sequentially activating the fluorescence in the LD of selected cells. In addition, the authors showed the difference in the number of LDs in lung cancer cells and normal lung cells.

Further efforts of Tang et al. resulted in a NIR AIEgen-based LD probe to stain LDs (TPE-AC Figure 6) [53]. By simple modification of the TE core with another electron-accepting group, 
malononitrile (instead of carbonyl in TPE-AmAI), the spectral properties of TE were tuned from blue emission to the NIR region, which was an AIEgen named TPE-AC. TPE-AC aggregates in water and shows a NIR emission at $780 \mathrm{~nm}$, with an absolute quantum yield of $5 \%$ in the solid state. Surprisingly, unlike TPE-AmAI, there was no blue-shifted emission for TPE-AC once it stains cellular LDs, as it preserved its emission in the NIR region similar to in aqueous solution.

The redesign of the triphenylamine core led to the discovery of red/NIR AIEgens, TPMN, TTMN, MeTTMN, and MeOTTMN (Figure 6) [54]. Ranging their emission from $648 \mathrm{~nm}$ to $719 \mathrm{~nm}$ in the solid state, these AIEgens exhibited interesting characteristics such as synthetically one-pot accessible molecules, large Stokes shifts, and bright emissions. They were shown to specifically stain LDs in a co-localization experiment with lipophilic BODIPY 493/503. The reported AIEgens demonstrated the capacity to produce reactive oxygen species, and thus open the venue to be utilized as photodynamic therapy sensitizers. In addition, TPMN, TTMN, and MeTTMN enabled fluorescence imaging in live zebrafish embryos.

The same group recently reported carbazole-bridged push-pull NIR AIEgens named DCMa, DCIs, and DCFu (Figure 6) [55]. These luminogenic molecules exhibited polarity-dependent solvatochromism. In polar solvent, they are non-emissive due to the TICT effect. In aggregated form, their emission ranged from $665 \mathrm{~nm}$ to $775 \mathrm{~nm}$. DCMa, DCIs, and DCFu stained LDs suggested by the co-localization with BODIPY 505/515. All three dyes were two-photon excitable and showed moderate photosensitizing properties to generate reactive oxygen species.

One of the latest approaches to developing a NIR LD probe resulted in the discovery of NLV-1 (Figure 6) [56]. NLV-1 is a merocyanine composed of an indolenine part and a malonitrile moiety (Figure 6). The fluorogenic property of the molecule is caused by free rotation motion in low viscous media and stabilization of the planar emissive form in highly viscous media. Owing to such a property, NLV-1 can report viscosity changes in LDs. The probe displayed a red shift in absorption from $644 \mathrm{~nm}$ to $680 \mathrm{~nm}$ (from methanol to glycerol), while weak emission at $704 \mathrm{~nm}$ in methanol enhanced and shifted to $719 \mathrm{~nm}$ in glycerol. The turn-on fluorescence effect was 13.77-fold. Even though NLV-1 can target LDs in cells, it fluoresces only when native LDs environment viscosity is increased by the treatment of viscosity modulators (Monesin, Nystatin) [56]. This property is indeed useful to study the viscosity changes of LDs, but makes it impractical to use NLV-1 as an LD label under physiological conditions.

\subsection{Families of LD Probes with Tunable Emission Color}

Recently available LipidTox ${ }^{\mathrm{TM}}$ Neutral Lipid Stains by Thermofisher were developed to characterize the intracellular accumulation of neutral lipids [57]. Unfortunately, their structural information has not yet been disclosed. LipidTox ${ }^{\mathrm{TM}}$ Neutral Lipid Stains are available in three colors: green $\left(\lambda_{x / \mathrm{em}}=495 / 505\right)$, red $\left(\lambda_{x / \mathrm{em}}=577 / 609\right)$, and deep red $\left(\lambda_{x / \mathrm{em}}=637 / 655\right)$. The series of LDs stains was reported to be more specific to LDs in comparison to Nile Red. The drawback is the compatibility for fixed cells only.

In 2018, a family of six fluorogenic dyes named StatoMerocynaines (SMCy) was introduced (Figure 6) [23]. SMCy exhibited impressive performance as fluorescent LD-targeting probes (Figure 5) [23]. The structure of SMCy is composed of barbiturate-based merocyanine with a dioxaborine bridge. Its design included: (i) two cyclohexyl rings to increase the molecule hydrophobicity and bulkiness that can help in preventing non-specific staining; (ii) the non-charged nature favoring attraction to a neutral lipid-rich environment; (iii) the length of the polymethine chain and extension benzoindolenine moiety instead of indolenine to provide the tunability of the photophysical properties; (iv) a dioxaborine bridge to fix a degree of rotation of the fluorophore and therefore enhances its brightness, moreover; and (v) a pentynyl tail to give the opportunity to functionalize the dye via bioorthogonal chemistry.

In oil, the SMCy mostly displayed narrow absorption and emission spectra and spanned their fluorescence from yellow to the NIR (from $541 \mathrm{~nm}$ to $753 \mathrm{~nm}$ ). The brightness of SMCy was 
solvent-dependent; they generally displayed high molar extinction coefficients up to an impressive value of $394,000 \mathrm{M}^{-1} \cdot \mathrm{cm}^{-1}$ and quantum yields of $100 \%$. In the light of the high lipophilic nature of the SMCy dyes, their photophysical properties were measured in water and colza oil (which was mainly composed of unsaturated long chain triglycerides). Remarkably, SMCy fluorogenic dyes showed up to 1700-fold fluorescence enhancement from water to oil, which is significantly larger compared to other reported LD probes. The fluorogenic behavior could be assigned to a combination of different factors. First, the considerable ICT character of these dyes makes them more fluorescent in less polar and viscous media. Second, in water, they undergo aggregation-caused quenching, which makes them non-fluorescent in aqueous media. This unprecedented light-up effect of SMCy dyes provided a background-free fluorescence imaging of LDs. SMCy co-localized well with both Nile Red and BODIPY 493/503. Interestingly, orthogonally colored SMCy were able to cross-co-localize as well. While IND-TPA can be used for tracking the dynamic motions of LDs in live cells, whether IND-TPA is compatible in multicolor multiorganelle tracking such as SMCy was not shown.

SMCy 3 was shown to be an efficient "green" LD marker [23]. Due to its sharp excitation and emission and its high brightness $\left(\varepsilon=87,000 \mathrm{M}^{-1} \mathrm{~cm}^{-1}, \phi=0.25\right.$ in oil), SMCy 3 provides a robust fluorescence signal from cellular LDs in the green channel, minimizing cross-talk in the channels of other colors.

We showed that four out of six members SMCys displayed remarkably high 2PA cross-section values. Notably, SMCy 5.5 displayed 10,400 GM at $820 \mathrm{~nm}$. Combined to its quantum yield close to unity in lipid-rich environments, this probe is, to our best knowledge, the brightest 2PE fluorophore [23]. Using SMCy 5.5, we were able to map LDs in mouse adipose tissue in multicolor 2PE fluorescence imaging, providing high quality images. A reconstruction of a 52- $\mu \mathrm{m}$ depth 3D 2PE image revealed clear localization of the nuclei, the LDs, as well as the collagen fibers (using second harmonic generation). Owning to their sharp absorption and emission peaks and color availability, SMCy were shown to be perfectly compatible with multicolor imaging in cells and tissues.

\section{Application of Fluorescent LD Probes}

For a long time, LDs were considered simple neutral lipids reservoirs [1,2]. Until recently, its important role as a dynamic organelle in many cellular bioprocesses, in particular metabolic bioprocesses, was reevaluated [58]. Conventional lipid dyes (Nile Red, BODIPY 493/503) permitted shining light on the elucidation of fundamental LD-associated biological processes such as the lipid biosynthesis and further storage in LDs, as well as its association with endoplasmic reticulum (ER) and communication with other cellular compartments [3,15,59]. Also, BODIPY 493/503 was able to sense nuclear LDs [60] and revealed the LDs' biogenesis in hepatitis C-infected cells [61]. Interestingly, the sensitivity of lipophilic dyes is sufficient for monitoring the formation and degradation of LDs under stress conditions in mammalian cells [62] and bacterial pathogens [63,64]. Lipophilic BODIPY $665 / 676$ found its utility to study the dynamics of milk LDs' growth during mice lactation, revealing oxytocin-dependent LDs secretion [65].

Since lipid uptake by monocytes induces inflammation and this is directly connected to an elevated LD content, Nile Red served as a platform in the development of a quantitative imaging-based analysis of lipid accumulation [66]. Recently BioTek ${ }^{\circledR}$ has developed a phenotypic-based assay using lipophilic dyes (Nile Red and BODIPY 493/503) to probe LDs formation in hepatic HepG2 cells associated with non-alcoholic fatty liver disease (NAFLD) caused by fatty acids overload [67]. However, Nile Red was also able to detect alterations in neutral LD content in circulating monocytes derived from patients [66] and report LDs NAFLD-associated overproduction [67].

Emerged fluorescent chemical LDs probes enabled new discoveries in LDs research. One can mention efforts to apply them in biofuels studies (Figure 7B) [30,44]. Microalgae attracted considerable attention in biofuel research as an alternative energy source, since it is highly rich in lipid content. Lipid-abundant reservoirs in these organisms correlate with biomass productivity. SF44 [43], SF58 [44], and TPE-AmAl [30] were shown to robustly stain the algal LDs with high specificity to find high 
biofuel algae species. In addition, SF44 was subjected to develop a high-throughput screening (HTS) assay to find a small molecule modulator of intracellular LDs. Impressively, SF44-based screening assay led to the discovery of P8B05 that promotes LD formation in cells [43].

Some LDs probes found applications in in vivo imaging. BTD-Lip was able to selectively stain LDs in the worm, displaying a clear-cut distribution of LDs inside the organism, but not in the posterior region of the body, which is known to lack lipid-rich organelles (Figure 7E). The green-emitting LipidGreen and LipidGreen2 were successfully applied to image fat depots in zebrafish [32,33]. LipidGreen was able to monitor lipid synthesis and mobilization during the fasting and feeding cycles of zebrafish (Figure 7F). Also, LipidGreen potential was explored in drug screening for diacylglycerol acyltransferase 1 (DGAT1) inhibitors. DGAT1 is an enzyme that is responsible for the esterification of 1,2-diacylglycerol to form triglycerides, which are a main component of the LDs core; therefore, DGAT1 is a promising therapeutic target for metabolic regulations. The NIR emissive NLV-1 probe was applied to detect viscosity changes in zebrafish under the treatment of viscosity modulators and in living mice under Lipopolysaccharide-induced inflammation conditions [56]. Indeed, NLV-1 can nicely report viscosity alterations, but its non-specificity in complex living organisms may complicate the data analysis.
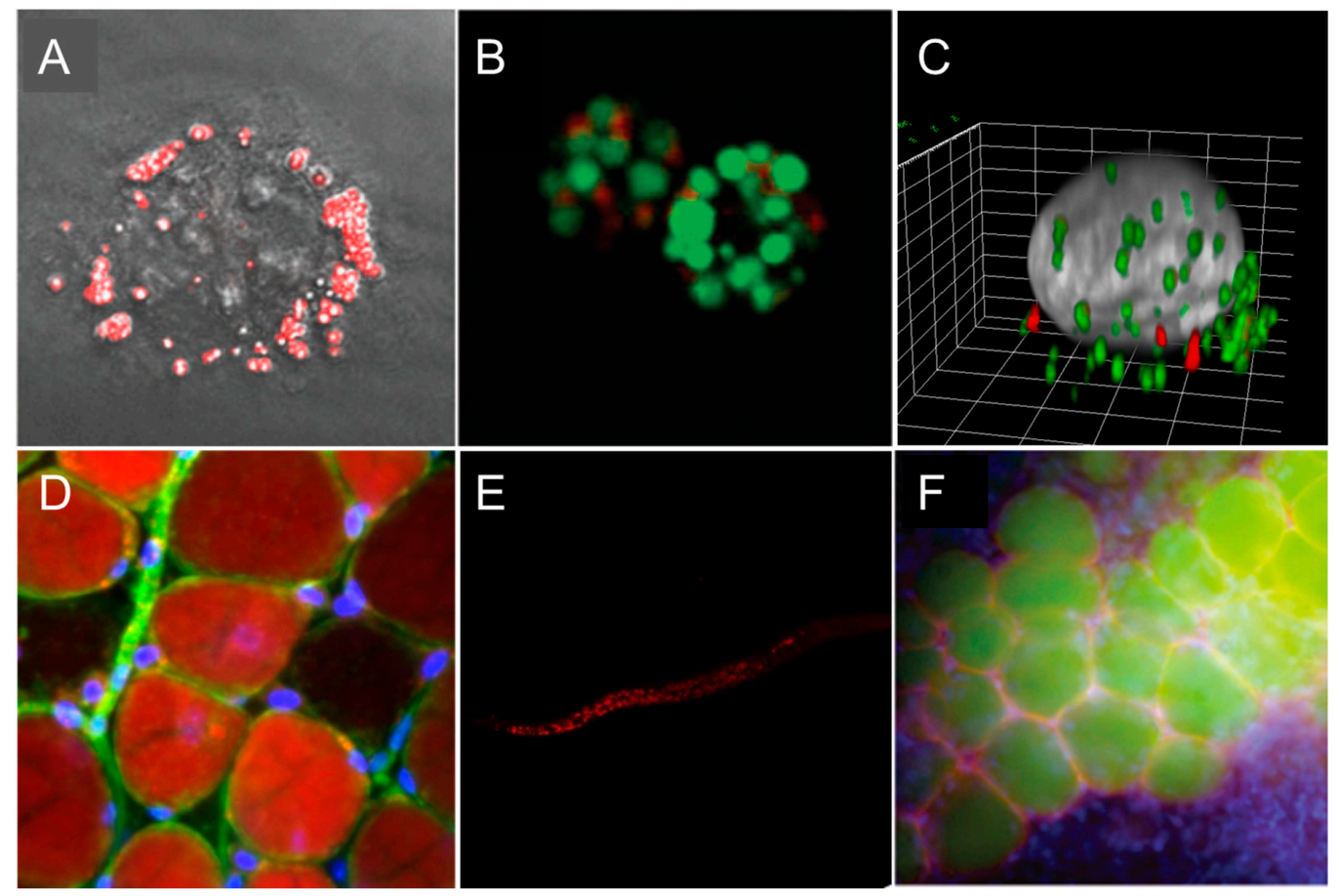

Figure 7. Representative fluorescence microscopy images of LDs. (A) Two-photon excited fluorescence image of LDs labeled with IND-TPA in HCC827 cells [47]. (B) LDs of green algae stained by SF44 (in green); fluorescence from chlorophyll (in red) [44]. (C) Three-dimensional (3D) view of a KB (HeLa derivative) cell displaying exchanged LDs from another cell (SMCy 3.5 in green and SMCy 5.5 in red) [23]. (D) Image of adipocytes in mouse adipose tissue ( $25 \mu \mathrm{m}$ depth) obtained by a maximum projection of a Z-stack (100 slices of 250-nm depth each). LDs were stained with SMCy 3.5 (in red), nuclei in blue, and plasma membrane in green [23]. (E) Images of LDs stained with BTD-Lip (in red) in C. elegans (worm) [46]. (F) LDs imaging with LipidGreen (in green) in vertebral adipose tissues of zebrafish (nucleus in blue, LD-associated protein in red) [32]. Images $(\mathbf{A}, \mathbf{B}, \mathbf{F})$ were reproduced with permission from The Royal Society of Chemistry. Images $(\mathbf{C}, \mathbf{D}, \mathbf{E})$ were reproduced with permission from the American Chemical Society.

Two-photon excitation (2PE) microscopy became widely used as an advanced optical imaging technique for biomedical research [68]. 2PE imaging, in addition to reducing cell auto fluorescence, 
permits the long-term monitoring of cellular network dynamics while providing high spatio-temporal resolution in both cells and deep tissue samples. For these reasons, the inevitable demand resulted in the development of $2 \mathrm{PE}$-fluorescent probes for LDs research. Hence, $\mathrm{MDH}\left(\delta_{2 \mathrm{PA}}\right.$ is not provided) [26], TPA-BI $\left(\delta_{2 \mathrm{PA}}=213 \mathrm{GM}\right.$ at $\left.840 \mathrm{~nm}\right)$ [31], LD-TPZn $\left(\delta_{2 \mathrm{PA}}=110 \mathrm{GM}\right.$ at $\left.880 \mathrm{~nm}\right)$ [50], IND-TPA $\left(\delta_{2 \mathrm{PA}}=119 \mathrm{GM}\right.$ at $\left.920 \mathrm{~nm}\right)$ [47] (Figure 7A), and the family of SMCy dyes $\left(\delta_{2 \mathrm{PA}}=178-13,330 \mathrm{GM}\right)$ [23] were developed as 2PE LD fluorescent probes. Most of these dyes were able to image LDs under fatty acids-stressed conditions, the brightest to date two-photon excitable SMCy 5.5 was able to map LDs in mouse liver tissue under physiological conditions. Due to its extreme brightness and near-infrared emission, the further utilization of SMCy dyes in 2PE imaging of tissues or in vivo living animals imaging will facilitate discoveries in the field of LDs.

SMCy 3.5 was successfully used to stain large LDs in adipocytes as well as small circulating ones in the blood vessels (Figure 7D). Additionally, the color palette availability of LDs markers provides the opportunity to track the LDs of different populations within the same set of experiments (Figure 7C). Thus, SMCy dyes enabled demonstrating the occurrence of time-dependent cell-to-cell LDs exchange: it was shown that exchange took place after $48 \mathrm{~h}$ of intercellular interaction, which is not the case after $4 \mathrm{~h}$ or $18 \mathrm{~h} \mathrm{[23].}$

Table 1 sums up the photophysical properties of the reviewed LD probes as well as their applications.

Table 1. Photophysical properties of LDs probes and their applications.

\begin{tabular}{|c|c|c|c|c|c|c|}
\hline Dye & $\lambda_{\mathrm{ex}} / \lambda_{\mathrm{em}}, \mathrm{nm}$ & $\begin{array}{l}\varepsilon, \mathbf{M}^{-1} \\
\mathrm{~cm}^{-1}\end{array}$ & QY & Excitation Mode & Application & Reference \\
\hline \multicolumn{7}{|l|}{ Commonly used } \\
\hline Nile Red & $553 / 635(\mathrm{MeOH})$ & 44,000 & n.r. & $1 \mathrm{P}$ & Cells & [21] \\
\hline BODIPY 493/503 & $493 / 503(\mathrm{MeOH})$ & 90,000 & n.r. & $1 \mathrm{P}$ & Cells & [22] \\
\hline \multicolumn{7}{|l|}{ Blue } \\
\hline PITE & $313^{\mathrm{a}} / 487(\mathrm{MeCN})$ & n.r. & $0.48(\mathrm{MeCN})$ & $1 \mathrm{P}$ & Mammalian and bacterial cells & [28] \\
\hline $\mathrm{MDH}$ & $405 / 570(\mathrm{MeOH})$ & n.r. & n.r. & $1 \mathrm{P}, 2 \mathrm{P}\left(\delta_{2 \mathrm{PA}}\right.$ n.r. $)$ & Cells & [26] \\
\hline TPA-BI & $447 / 619(\mathrm{MeCN})$ & 34,000 & 0.22 (water $70 \%$ ) & $\begin{array}{l}1 \mathrm{P}, 2 \mathrm{P}\left(\delta_{2 \mathrm{PA}}=213 \mathrm{GM}\right. \\
\text { at } 840 \mathrm{~nm})\end{array}$ & $1 \mathrm{PE}$ and $2 \mathrm{PE}$ imaging in cells & [31] \\
\hline TPE-AmAl & $400 / 470$ (THF) & n.r. & 0.22 (solid state) & $1 \mathrm{P}$ & Cells and algae & [30] \\
\hline PyrPy 10d & $356 / 449\left(\mathrm{CHCl}_{3}\right)$ & 12,400 & $0.322\left(\mathrm{CHCl}_{3}\right)$ & $1 \mathrm{P}$ & Cells & [27] \\
\hline PyrPy 11c & $344 / 447\left(\mathrm{CHCl}_{3}\right)$ & 13,200 & $0.029\left(\mathrm{CHCl}_{3}\right)$ & $1 \mathrm{P}$ & Cells & [27] \\
\hline \multicolumn{7}{|l|}{ Green } \\
\hline BODIPY 505/515 & 505/515(MeOH) & 94,000 & n.r. & $1 \mathrm{P}$ & Cells & [22] \\
\hline LipidGreen & $485 / 515$ (PBS) & n.r. & n.r. & $1 \mathrm{P}$ & See footnote 1 & [32] \\
\hline LipidGreen2 & 456/534 (PBS) & n.r. & n.r. & $1 \mathrm{P}$ & See footnote 2 & [33] \\
\hline LD540 & $540 / 545.5$ (oil) & n.r. & n.r. & $1 \mathrm{P}$ & Multicolor imaging in cells & [34] \\
\hline LD-BTD1 & 420/511 (hexane) & 7100 & 0.66 (hexane) & $1 \mathrm{P}$ & Cells & [37] \\
\hline AF8 & 380/479 (DMSO) & n.r. & 0.31 (DMSO) & $1 \mathrm{P}$ & Cells & [35] \\
\hline AFN & $428 / 592$ (DMSO) & n.r. & 0.17 (DMSO) & $1 \mathrm{P}$ & Cells & [35] \\
\hline AF10 & 356/477 (DMSO) & n.r. & 0.18 (DMSO) & $1 \mathrm{P}$ & Cells & [35] \\
\hline $\mathrm{NAP}-\mathrm{Ph}$ & 409/523 (water) & n.r. & 0.018 (water) & $\begin{array}{l}1 \mathrm{P}, 2 \mathrm{P}\left(\delta_{2 \mathrm{PA}}=100 \mathrm{GM}\right. \\
\text { at } 860 \mathrm{~nm})\end{array}$ & $\begin{array}{l}1 \mathrm{PE} \text { and } 2 \mathrm{PE} \text { imaging in cells } \\
\text { and tissues }\end{array}$ & [36] \\
\hline NAP-Br & $409 / 525$ (water) & n.r. & 0.014 (water) & $\begin{array}{l}1 \mathrm{P}, 2 \mathrm{P}\left(\delta_{2 \mathrm{PA}}=\sim 50 \mathrm{GM}\right. \\
\text { at } 860 \mathrm{~nm})\end{array}$ & $\begin{array}{l}\text { 1PE and 2PE imaging in cells } \\
\text { and tissues }\end{array}$ & [36] \\
\hline $\mathrm{NAP}-\mathrm{CF}_{3}$ & $425 / 560$ (water) & n.r. & 0.016 (water) & $\begin{array}{l}1 \mathrm{P}, 2 \mathrm{P}\left(\delta_{2 \mathrm{PA}}=\sim 50 \mathrm{GM}\right. \\
\text { at } 860 \mathrm{~nm})\end{array}$ & $\begin{array}{l}1 \mathrm{PE} \text { and } 2 \mathrm{PE} \text { imaging in cells } \\
\text { and tissues }\end{array}$ & [36] \\
\hline NAP-Py & 413/541 (water) & n.r. & 0.015 (water) & $\begin{array}{l}1 \mathrm{P}, 2 \mathrm{P}\left(\delta_{2 \mathrm{PA}}=45 \mathrm{GM} \text { at }\right. \\
860 \mathrm{~nm})\end{array}$ & $\begin{array}{l}\text { 1PE and 2PE imaging in cells } \\
\text { and tissues }\end{array}$ & [36] \\
\hline LipiDye & 415 (toluene) & 18,700 & 0.94 (toluene) & $1 \mathrm{P}$ & Cells & {$[38,39]$} \\
\hline $\mathrm{PA}$ & 434/521 (toluene) & 25,000 & 0.95 (toluene) & $\begin{array}{l}1 \mathrm{P}, 2 \mathrm{P}\left(\delta_{2 \mathrm{PA}}=35 \mathrm{GM} \text { at }\right. \\
820 \mathrm{~nm})\end{array}$ & Lipid order in cells & [40] \\
\hline Phos 2a & 439/554 (DMSO) & n.r. & n.r. & $1 \mathrm{P}$ & Cells & [41] \\
\hline Phos 3a & $429 / 512$ (DMSO) & n.r. & n.r. & $1 \mathrm{P}$ & Cells & [41] \\
\hline Phos $2 b$ & $437 / 554$ (DMSO) & n.r. & n.r. & $1 \mathrm{P}$ & Not applicable for cells & [41] \\
\hline Phos $3 b$ & 374/550 (DMSO) & n.r. & n.r. & $1 \mathrm{P}$ & Not applicable for cells & [41] \\
\hline P1 & 428/500 (Dioxane) & n.r. & 0.22 & $1 \mathrm{P}$ & Cells & [42] \\
\hline
\end{tabular}


Table 1. Cont.

\begin{tabular}{|c|c|c|c|c|c|c|}
\hline Dye & $\lambda_{\mathrm{ex}} / \lambda_{\mathrm{em}}, \mathrm{nm}$ & $\begin{array}{l}\varepsilon, \mathrm{M}^{-1} \\
\mathrm{~cm}^{-1}\end{array}$ & QY & Excitation Mode & Application & Reference \\
\hline \multicolumn{7}{|l|}{ Orange } \\
\hline SF44 & $455 / 626(\mathrm{MeCN})$ & n.r. & $0.09(\mathrm{MeCN})$ & $1 \mathrm{P}$ & Cells, HTS for LD modulator & [43] \\
\hline SF58 & $440 / 623(\mathrm{MeCN})$ & n.r. & $0.09(\mathrm{MeCN})$ & $1 \mathrm{P}$ & Cells and algae & [44] \\
\hline FAS & $322 / 600$ (water) $^{\mathrm{b}}$ & n.r. & $\begin{array}{l}0.021 \text { (solid } \\
\text { state) }\end{array}$ & $1 \mathrm{P}$ & Cells & [45] \\
\hline DPAS & $301 / 550$ (water) ${ }^{b}$ & n.r. & 0.03 (solid state & $1 \mathrm{P}$ & Cells & [45] \\
\hline BTD-Lip & $455 / 624(\mathrm{MeCN})$ & 7586 & $0.2(\mathrm{MeCN})$ & $1 \mathrm{P}$ & Cells and worms & [46] \\
\hline IND-TPA & $478 / 594$ (THF) & n.r. & 0.069 (THF) & $\begin{array}{l}1 \mathrm{P}, 2 \mathrm{P}\left(\delta_{2 \mathrm{PA}}=119 \mathrm{GM}\right. \\
\text { at } 920 \mathrm{~nm})\end{array}$ & $1 \mathrm{PE}$ and $2 \mathrm{PE}$ imaging in cells & [47] \\
\hline BZT 3a & 309/576 (water) & n.r. & n.r. & $1 \mathrm{P}, 2 \mathrm{P}$ at $780 \mathrm{~nm}$ & $1 \mathrm{PE}$ and $2 \mathrm{PE}$ imaging in cells & [49] \\
\hline BZT 4a & $-/ 570$ (solid) & n.r. & 0.4 (solid state) & $1 \mathrm{P}, 2 \mathrm{P}$ at $780 \mathrm{~nm}$ & $1 \mathrm{PE}$ and $2 \mathrm{PE}$ imaging in cells & [49] \\
\hline \multicolumn{7}{|l|}{ Red to NIR } \\
\hline LD-TPZn & 599/630 (DMSO) & 10,600 & 0.44 (DMSO) & $\begin{array}{l}1 \mathrm{P}, 2 \mathrm{P}\left(\delta_{2 \mathrm{PA}}=110 \mathrm{GM}\right. \\
\text { at } 880 \mathrm{~nm})\end{array}$ & $1 \mathrm{PE}$ and $2 \mathrm{PE}$ imaging in cells & [50] \\
\hline LQD & $\begin{array}{c}495 / 600 \\
\text { (colloidal) }\end{array}$ & n.r. & n.r. & $1 \mathrm{P}$ & Cells & [51] \\
\hline PhotoAFN 2a & $409 / 624$ (THF) & n.r. & 0.006 (THF) & $1 \mathrm{P}$ & Cells & [52] \\
\hline PhotoAFN 2b & 402/617 (THF) & n.r. & 0.005 (THF) & $1 \mathrm{P}$ & Cells & [52] \\
\hline PhotoAFN 2c & $400 / 610$ (THF) & n.r. & 0.008 (THF) & $1 \mathrm{P}$ & Cells & [52] \\
\hline TPE-AC & $455 / 724$ (THF) & n.r. & 0.05 (solid state) & $1 \mathrm{P}$ & Cells & [53] \\
\hline TPMN & $441 / 635(\mathrm{MeCN})$ & n.r. & $0.0021(\mathrm{MeCN})$ & $1 \mathrm{P}$ & Cells and zebrafish & [54] \\
\hline TTMN & $483 / 664(\mathrm{MeCN})$ & n.r. & $0.0032(\mathrm{MeCN})$ & $1 \mathrm{P}$ & Cells and zebrafish & [54] \\
\hline MeTTMN & $441 / 635(\mathrm{MeCN})$ & n.r. & $0.0021(\mathrm{MeCN})$ & $1 \mathrm{P}$ & Cells and zebrafish & [54] \\
\hline MeOTTMN & $499 /-(\mathrm{MeCN})$ & n.r. & n.r. & $1 \mathrm{P}$ & Cells & [54] \\
\hline DCMa & $478 / 665$ (water) & n.r. & $\begin{array}{l}0.296 \text { (solid } \\
\text { state) }\end{array}$ & $\begin{array}{l}1 \mathrm{P}, 2 \mathrm{P}\left(\delta_{2 \mathrm{PA}}=394 \mathrm{GM}\right. \\
\text { at } 940 \mathrm{~nm})\end{array}$ & $1 \mathrm{PE}$ and $2 \mathrm{PE}$ imaging in cells & [54] \\
\hline DCIs & $510 / 709$ (water) & n.r. & $\begin{array}{l}0.135 \text { (solid } \\
\text { state) }\end{array}$ & $\begin{array}{l}1 \mathrm{P}, 2 \mathrm{P}\left(\delta_{2 \mathrm{PA}}=548 \mathrm{GM}\right. \\
\text { at } 980 \mathrm{~nm})\end{array}$ & $1 \mathrm{PE}$ and $2 \mathrm{PE}$ imaging in cells & [55] \\
\hline DCFu & $538 / 755$ (water) & n.r. & $\begin{array}{l}0.017 \text { (solid } \\
\text { state) }\end{array}$ & $\begin{array}{l}1 \mathrm{P}, 2 \mathrm{P}\left(\delta_{2 \mathrm{PA}}=887 \mathrm{GM}\right. \\
\text { at } 1020 \mathrm{~nm})\end{array}$ & $1 \mathrm{PE}$ and $2 \mathrm{PE}$ imaging in cells & [55] \\
\hline v NLV-1 & 680/719 (glycerol) & n.r. & 0.204 (glycerol) & $1 \mathrm{P}$ & See footnote 3 & [56] \\
\hline \multicolumn{7}{|l|}{ Multicolor } \\
\hline LipidTox $^{\mathrm{TM}}$ & & & & & Analysis of steatosis & [57] \\
\hline green & $495 / 505$ & n.r. & n.r. & $1 \mathrm{P}$ & & [57] \\
\hline red & $577 / 609$ & n.r. & n.r. & $1 \mathrm{P}$ & & [57] \\
\hline deep red & $637 / 655$ & n.r. & n.r. & $1 \mathrm{P}$ & & [57] \\
\hline SMCy family & & & & & See footnote 4 & [23] \\
\hline SMCy3 & $512 / 541$ (oil) & 82,900 & 0.21 (oil) & $\begin{array}{l}1 \mathrm{P}, 2 \mathrm{P}\left(\delta_{2 \mathrm{PA}}=178 \mathrm{GM}\right. \\
\text { at } 690 \mathrm{~nm}, \mathrm{DMSO})\end{array}$ & & [23] \\
\hline SMCy3.5 & $530 / 559$ (oil) & 100,000 & 0.4 (oil) & $\begin{array}{l}1 \mathrm{P}, 2 \mathrm{P}\left(\delta_{2 \mathrm{PA}}=2400 \mathrm{GM}\right. \\
\text { at } 760 \mathrm{~nm}, \mathrm{DMSO})\end{array}$ & & [23] \\
\hline SMCy5 & 618/648 (oil) & 256,000 & 0.6 (oil) & $\begin{array}{l}1 \mathrm{P}, 2 \mathrm{P}\left(\delta_{2 \mathrm{PA}}=6250 \mathrm{GM}\right. \\
\text { at } 740 \mathrm{~nm}, \mathrm{DMSO})\end{array}$ & & [23] \\
\hline SMCy5.5 & 638/662 (oil) & 169,000 & 0.74 (oil) & $\begin{array}{l}1 \mathrm{P}, 2 \mathrm{P}\left(\delta_{2 \mathrm{PA}}=13330 \mathrm{GM}\right. \\
\text { at } 770 \mathrm{~nm} \text { and } 10400 \\
\mathrm{GM} \text { at } 820 \mathrm{~nm}, \mathrm{DMSO})\end{array}$ & & [23] \\
\hline SMCy7 & 692/744 (oil) & 44,000 & 0.42 (oil) & $1 \mathrm{P}$ & & [23] \\
\hline SMCy7.5 & 716/753 (oil) & 103,000 & 0.19 (oil) & $1 \mathrm{P}$ & & [23] \\
\hline
\end{tabular}

n.r. not reported. ${ }^{a}$ For tetraphenylethylene (TE) region; ${ }^{b}$ Emission of keto form. Footnote 1: Imaging in cells and zebrafish. Monitoring lipid synthesis and mobilization during fasting and feeding cycles. Drug screening for diacylglycerol acyltransferase 1 (DGAT1) inhibitor. Footnote 2: Imaging in cells and zebrafish. Early identification of hepatosteatosis. Footnote 3: Viscosity changes in cellular LDs, zebrafish, and mice. Footnote 4: Multicolor imaging of cells and tissues. LD tracking and intracellular exchange.

\section{Conclusions and Perspectives}

As outlined above, small-molecule LD-targeting fluorescent probes have already contributed in LDs research, revealing their niche role in cellular metabolism. Significant progress has already been made in the development of new LD-specific probes, including: (1) the range of available emission colors was expanded, and now span from blue to NIR; (2) efficient LDs probes that are compatible with 2PE are now available; (3) the selectivity toward LDs was improved; (4) some 
photophysical properties were enhanced such as: higher brightness, photostability, and Stokes shifts. Most of described probes exhibit solvatochromic and fluorogenic properties, which can originate from different photophysical mechanisms, such as ICT, TICT, AIE, and aggregation-caused quenching [14]. First, the dyes are based on ICT processes that have a strong electron-donating group and good electron-accepting moiety (PyrPy probes [27], Seoul Fluor probes [43,44], azafluorenone [35], and probes based on benzothiadiazole core $[37,46]$. The other mechanism involves aggregation-caused quenching (ACQ), where the molecules, being aggregated and non-fluorescent in aqueous media, become highly emissive after binding lipid droplets in molecular form. This mechanism concerns the SMCy family and many other lipophilic LD probes. The third distinguished group utilizes two photophysical fluorescence-activating principals, twisted ICT (TICT) and AIE (the probes based on tetraphenylethylene core as an AIE-driving force [30,31,47,49,53,55]. The AIEgens are usually weakly emissive in organic solvent solutions, but they are strongly fluorescent in an aggregated state in aqueous media (as nanoparticles or solid film). While developed AIE-based bioprobes demonstrated their utility to stain LDs, they usually displayed blue-shifted emission in LDs in comparison to the emission in water, except for TPE-AC, DCMa, DCIs, and DCFu which preserved its NIR fluorescence [53,55]. The fluorescent probes described here have enabled the visualization and detection of LDs in cells, tissues, and living animals.

We anticipate that continued progress will be made to develop new LD-specific probes, such as probes that can be used in multimodal imaging techniques to increase the credibility of the obtained results. For instance, the introduction of radioactive isotopes to the core of reported LD-specific probes would open the opportunity to use a positron emission tomography (PET) imaging technique in addition to the fluorescence. In particular, the introduction of the radioisotope ${ }^{18} \mathrm{~F}$ would be significant, since it has longer lifetime in comparison to commonly used ${ }^{3} \mathrm{H}$ and ${ }^{14} \mathrm{C}$, and is already widely used in clinics (for example, fludeoxyglucose $\left({ }^{18} \mathrm{~F}\right)$ is used for cancer diagnostics). Emerging advances in stimulated Raman scattering (SRS) imaging technology allowed the visualization of alkyne-tagged small molecules in live cells [69]. The alkyne tag exhibits a defined strong stretching bond signal of $\mathrm{C} \equiv \mathrm{C}$ at $\sim 2100 \mathrm{~cm}^{-1}$; therefore, SMCy dyes can potentially be used in SRS imaging for cellular LDs in addition to fluorescence. Interestingly, the nitrile $\mathrm{C} \equiv \mathrm{N}$ bond has a characteristic peak at $\sim 2200 \mathrm{~cm}^{-1}$; thus, fluorophores such as NLV-1, LD-TPZn, TPE-AC, DCMa, DCIs, TPMN, TTMN, MeTTMN, and MeOTTMN might have a potential in SRS imaging techniques. Thus, the application of the single probe for LDs in multimodal imaging settings will improve the fidelity of the acquired data.

In further efforts, it is essential to establish stronger collaborations between chemists and biologists for tuning the LD research, not only as tool-making oriented, but also as a bona fide solution that is oriented to better understanding the LD role in biological processes.

Author Contributions: T.K.F.; Writing-Original Draft Preparation, T.K.F., A.S.K. and M.C.; Writing-Review \& Editing; A.S.K. and M.C.; Supervision.

Funding: This research was funded by ERC Consolidator grant BrightSens 648528, ANR BrightRiboProbes (ANR-16-CE11-0010).

Acknowledgments: The authors would like to thank Hisashi Satoh for the invitation to publish in the special issue of Materials: "Fluorescent Sensors for Selective Detection ". The authors also thank The Royal Society of Chemistry and the American Chemical Society for the permission for the preproduction of the images in Figure 7.

Conflicts of Interest: The authors declare no conflict of interest.

\section{References}

1. Martin, S.; Parton, R.G. Opinion: Lipid Droplets: A Unified View of a Dynamic Organelle. Nat. Rev. Mol. Cell Biol. 2006, 7, 373-378. [CrossRef] [PubMed]

2. Farese, R.V.; Walther, T.C. Lipid Droplets Finally Get a Little R-E-S-P-E-C-T. Cell 2009, 139, 855-860. [CrossRef] [PubMed]

3. Thiam, A.R.; Farese, R.V., Jr.; Walther, T.C. The Biophysics and Cell Biology of Lipid Droplets. Nat. Rev. Mol. Cell Biol. 2013, 14, 775-786. [CrossRef] [PubMed] 
4. Blom, T.; Somerharju, P.; Ikonen, E. Synthesis and Biosynthetic Trafficking of Membrane Lipids. CSH Perspect. Biol. 2011, 3, a004713. [CrossRef] [PubMed]

5. Olzmann, J.A.; Richter, C.M.; Kopito, R.R. Spatial Regulation of UBXD8 and P97/VCP Controls ATGL-Mediated Lipid Droplet Turnover. Proc. Natl. Acad. Sci. USA 2013, 110, 1345-1350. [CrossRef] [PubMed]

6. Onal, G.; Kutlu, O.; Gozuacik, D.; Dokmeci Emre, S. Lipid Droplets in Health and Disease. Lipids Health Dis. 2017, 16, 128. [CrossRef] [PubMed]

7. Fujimoto, T.; Ohsaki, Y.; Suzuki, M.; Cheng, J. Chapter 13-Imaging Lipid Droplets by Electron Microscopy. In Methods in Cell Biology; Yang, H., Li, P., Eds.; Lipid Droplets; Academic Press: Cambridge, MA, USA, 2013; Volume 116, pp. 227-251.

8. Horn, P.J.; Ledbetter, N.R.; James, C.N.; Hoffman, W.D.; Case, C.R.; Verbeck, G.F.; Chapman, K.D. Visualization of Lipid Droplet Composition by Direct Organelle Mass Spectrometry. J. Biol. Chem. 2011, 286, 3298-3306. [CrossRef] [PubMed]

9. Abramczyk, H.; Surmacki, J.; Kopeć, M.; Olejnik, A.K.; Lubecka-Pietruszewska, K.; FabianowskaMajewska, K. The Role of Lipid Droplets and Adipocytes in Cancer. Raman Imaging of Cell Cultures: MCF10A, MCF7, and MDA-MB-231 Compared to Adipocytes in Cancerous Human Breast Tissue. Analyst 2015, 140, 2224-2235. [CrossRef] [PubMed]

10. Kim, K.; Lee, S.; Yoon, J.; Heo, J.; Choi, C.; Park, Y. Three-Dimensional Label-Free Imaging and Quantification of Lipid Droplets in Live Hepatocytes. Sci. Rep. 2016, 6, 36815. [CrossRef] [PubMed]

11. Lakowicz, J.R. Principles of Fluorescence Spectroscopy, 3rd ed.; Springer: New York City, NY, USA, 2006.

12. Lavis, L.D. Teaching Old Dyes New Tricks: Biological Probes Built from Fluoresceins and Rhodamines. Annu. Rev. Biochem. 2017, 86, 825-843. [CrossRef] [PubMed]

13. Zhu, H.; Fan, J.; Du, J.; Peng, X. Fluorescent Probes for Sensing and Imaging within Specific Cellular Organelles. Acc. Chem. Res. 2016, 49, 2115-2126. [CrossRef] [PubMed]

14. Klymchenko, A.S. Solvatochromic and Fluorogenic Dyes as Environment-Sensitive Probes: Design and Biological Applications. Acc. Chem. Res. 2017, 50, 366-375. [CrossRef] [PubMed]

15. Kuerschner, L.; Moessinger, C.; Thiele, C. Imaging of Lipid Biosynthesis: How a Neutral Lipid Enters Lipid Droplets. Traffic 2007, 9, 338-352. [CrossRef] [PubMed]

16. Listenberger, L.L.; Brown, D.A. Fluorescent Detection of Lipid Droplets and Associated Proteins. Curr. Protoc. Cell Biol. 2007, 35, 24. [CrossRef] [PubMed]

17. Aoki, T.; Hagiwara, H.; Fujimoto, T. Peculiar Distribution of Fodrin in Fat-Storing Cells. Exp. Cell Res. 1997, 234, 313-320. [CrossRef] [PubMed]

18. Koopman, R.; Schaart, G.; Hesselink, M.K. Optimisation of Oil Red O Staining Permits Combination with Immunofluorescence and Automated Quantification of Lipids. Histochem. Cell. Biol. 2001, 116, 63-68. [PubMed]

19. Ohsaki, Y.; Shinohara, Y.; Suzuki, M.; Fujimoto, T. A Pitfall in Using BODIPY Dyes to Label Lipid Droplets for Fluorescence Microscopy. Histochem. Cell. Biol. 2010, 133, 477-480. [CrossRef] [PubMed]

20. Fukumoto, S.; Fujimoto, T. Deformation of Lipid Droplets in Fixed Samples. Histochem. Cell. Biol. 2002, 118, 423-428. [CrossRef] [PubMed]

21. Greenspan, P.; Mayer, E.P.; Fowler, S.D. Nile Red: A Selective Fluorescent Stain for Intracellular Lipid Droplets. J. Cell Biol. 1985, 100, 965-973. [CrossRef] [PubMed]

22. Thermo Fisher Scientific. BODIPY 493/503. Available online: https://www.thermofisher.com/order/ catalog/product/D3922 (accessed on 26 July 2018).

23. Collot, M.; Fam, T.K.; Ashokkumar, P.; Faklaris, O.; Galli, T.; Danglot, L.; Klymchenko, A.S. Ultrabright and Fluorogenic Probes for Multicolor Imaging and Tracking of Lipid Droplets in Cells and Tissues. J. Am. Chem. Soc. 2018, 140, 5401-5411. [CrossRef] [PubMed]

24. Gocze, P.M.; Freeman, D.A. Factors Underlying the Variability of Lipid Droplet Fluorescence in MA-10 Leydig Tumor Cells. Cytometry 1994, 17, 151-158. [CrossRef] [PubMed]

25. Koreivienè, J. Microalgae Lipid Staining with Fluorescent BODIPY Dye. In SpringerLink; Methods in Molecular Biology; Humana Press: New York City, NY, USA, 2017; pp. 1-7.

26. Yang, H.-J.; Hsu, C.-L.; Yang, J.-Y.; Yang, W.Y. Monodansylpentane as a Blue-Fluorescent Lipid-Droplet Marker for Multi-Color Live-Cell Imaging. PLoS ONE 2012, 7, e32693. [CrossRef] [PubMed] 
27. Becerra-Ruiz, M.; Vargas, V.; Jara, P.; Tirapegui, C.; Carrasco, C.; Nuñez, M.; Lezana, N.; Galdámez, A.; Vilches-Herrera, M. Blue-Fluorescent Probes for Lipid Droplets Based on Dihydrochromeno-Fused Pyrazoloand Pyrrolopyridines. Eur. J. Org. Chem. 2018, 34, 4795-4801. [CrossRef]

28. Sk, B.; Thakre, P.K.; Tomar, R.S.; Patra, A. A Pyridoindole-Based Multifunctional Bioprobe: PH-Induced Fluorescence Switching and Specific Targeting of Lipid Droplets. Chem. Asian J. 2017, 12, 2501-2509. [CrossRef] [PubMed]

29. Mei, J.; Leung, N.L.C.; Kwok, R.T.K.; Lam, J.W.Y.; Tang, B.Z. Aggregation-Induced Emission: Together We Shine, United We Soar! Chem. Rev. 2015, 115, 11718-11940. [CrossRef] [PubMed]

30. Wang, E.; Zhao, E.; Hong, Y.; Lam, J.W.Y.; Tang, B.Z. A Highly Selective AIE Fluorogen for Lipid Droplet Imaging in Live Cells and Green Algae. J. Mater. Chem. B 2014, 2, 2013-2019. [CrossRef]

31. Jiang, M.; Gu, X.; Lam, J.W.Y.; Zhang, Y.; Kwok, R.T.K.; Wong, K.S.; Tang, B.Z. Two-Photon AIE Bio-Probe with Large Stokes Shift for Specific Imaging of Lipid Droplets. Chem. Sci. 2017, 8, 5440-5446. [CrossRef] [PubMed]

32. Lee, J.H.; So, J.-H.; Jeon, J.H.; Choi, E.B.; Lee, Y.-R.; Chang, Y.-T.; Kim, C.-H.; Bae, M.A.; Ahn, J.H. Synthesis of a New Fluorescent Small Molecule Probe and Its Use for in Vivolipid Imaging. Chem. Commun. 2011, 47, 7500-7502. [CrossRef] [PubMed]

33. Chun, H.-S.; Jeon, J.H.; Pagire, H.S.; Lee, J.H.; Chung, H.-C.; Park, M.J.; So, J.-H.; Ryu, J.-H.; Kim, C.-H.; Ahn, J.H.; et al. Synthesis of LipidGreen2 and Its Application in Lipid and Fatty Liver Imaging. Mol. BioSyst. 2013, 9, 630-633. [CrossRef] [PubMed]

34. Spandl, J.; White, D.J.; Peychl, J.; Thiele, C. Live Cell Multicolor Imaging of Lipid Droplets with a New Dye, LD540. Traffic 2009, 10, 1579-1584. [CrossRef] [PubMed]

35. Sharma, A.; Umar, S.; Kar, P.; Singh, K.; Sachdev, M.; Goel, A. A New Type of Biocompatible Fluorescent Probe AFN for Fixed and Live Cell Imaging of Intracellular Lipid Droplets. Analyst 2015, 141, 137-143. [CrossRef] [PubMed]

36. Niu, G.; Zhang, R.; Kwong, J.P.C.; Lam, J.W.Y.; Chen, C.; Wang, J.; Chen, Y.; Feng, X.; Kwok, R.T.K.; Sung, H.H.-Y.; et al. Specific Two-Photon Imaging of Live Cellular and Deep-Tissue Lipid Droplets by Lipophilic AIEgens at Ultralow Concentration. Chem. Mater. 2018, 30, 4778-4787. [CrossRef]

37. Appelqvist, H.; Stranius, K.; Börjesson, K.; Nilsson, K.P.R.; Dyrager, C. Specific Imaging of Intracellular Lipid Droplets Using a Benzothiadiazole Derivative with Solvatochromic Properties. Bioconjug. Chem. 2017, 28, 1363-1370. [CrossRef] [PubMed]

38. Yamaguchi, E.; Wang, C.; Fukazawa, A.; Taki, M.; Sato, Y.; Sasaki, T.; Ueda, M.; Sasaki, N.; Higashiyama, T.; Yamaguchi, S. Environment-Sensitive Fluorescent Probe: A Benzophosphole Oxide with an Electron-Donating Substituent. Angew. Chem. Int. Edit. 2015, 127, 4622-4626. [CrossRef]

39. High Sensitive Lipid Droplets Imaging Fluorescent Dye | LipiDye | Funakoshi Co., Ltd.: Tokyo, Japan. Available online: https:/ / www.funakoshi.co.jp/exports_contents/80682 (accessed on 30 July 2018).

40. Niko, Y.; Didier, P.; Mely, Y.; Konishi, G.; Klymchenko, A.S. Bright and Photostable Push-Pull Pyrene Dye Visualizes Lipid Order Variation between Plasma and Intracellular Membranes. Sci. Rep. 2016, 6, 18870. [CrossRef] [PubMed]

41. Öberg, E.; Appelqvist, H.; Nilsson, K.P.R. Non-Fused Phospholes as Fluorescent Probes for Imaging of Lipid Droplets in Living Cells. Front. Chem. 2017, 5. [CrossRef] [PubMed]

42. De Moliner, F.; King, A.; Dias, G.G.; de Lima, G.F.; de Simone, C.A.; da Silva Júnior, E.N.; Vendrell, M. Quinone-Derived $\pi$-Extended Phenazines as New Fluorogenic Probes for Live-Cell Imaging of Lipid Droplets. Front. Chem. 2018, 6. [CrossRef] [PubMed]

43. Kim, E.; Lee, S.; Park, S.B. A Seoul-Fluor-Based Bioprobe for Lipid Droplets and Its Application in Image-Based High Throughput Screening. Chem. Commun. 2012, 48, 2331-2333. [CrossRef] [PubMed]

44. Lee, Y.; Na, S.; Lee, S.; Jeon, N.L.; Park, S.B. Optimization of Seoul-Fluor-Based Lipid Droplet Bioprobes and Their Application in Microalgae for Bio-Fuel Study. Mol. Biosyst. 2013, 9, 952-956. [CrossRef] [PubMed]

45. Wang, Z.; Gui, C.; Zhao, E.; Wang, J.; Li, X.; Qin, A.; Zhao, Z.; Yu, Z.; Tang, B.Z. Specific Fluorescence Probes for Lipid Droplets Based on Simple AIEgens. ACS Appl. Mater. Interfaces 2016, 8, 10193-10200. [CrossRef] [PubMed] 
46. Mota, A.A.R.; Correa, J.R.; de Andrade, L.P.; Assumpção, J.A.F.; de Souza Cintra, G.A.; Freitas-Junior, L.H.; da Silva, W.A.; de Oliveira, H.C.B.; Neto, B.A.D. From Live Cells to Caenorhabditis Elegans: Selective Staining and Quantification of Lipid Structures Using a Fluorescent Hybrid Benzothiadiazole Derivative. ACS Omega 2018, 3, 3874-3881. [CrossRef] [PubMed]

47. Gao, M.; Su, H.; Li, S.; Lin, Y.; Ling, X.; Qin, A.; Tang, B.Z. An Easily Accessible Aggregation-Induced Emission Probe for Lipid Droplet-Specific Imaging and Movement Tracking. Chem. Commun. 2017, 53, 921-924. [CrossRef] [PubMed]

48. Grabowski, Z.R.; Rotkiewicz, K.; Rettig, W. Structural Changes Accompanying Intramolecular Electron Transfer: Focus on Twisted Intramolecular Charge-Transfer States and Structures. Chem. Rev. 2003, 103, 3899-4032. [CrossRef] [PubMed]

49. Li, S.; Ling, X.; Lin, Y.; Qin, A.; Gao, M.; Tang, B.Z. In Situ Generation of Photoactivatable AggregationInduced Emission Probes for Organelle-Specific Imaging. Chem. Sci. 2018, 9, 5730-5735. [CrossRef] [PubMed]

50. Tang, J.; Zhang, Y.; Yin, H.-Y.; Xu, G.; Zhang, J.-L. Precise Labeling and Tracking of Lipid Droplets in Adipocytes Using a Luminescent ZnSalen Complex. Chem. Asian J. 2017, 12, 2533-2538. [CrossRef] [PubMed]

51. Mandal, S.; Jana, N.R. Quantum Dot-Based Designed Nanoprobe for Imaging Lipid Droplet. J. Phys. Chem. C 2017, 121, 23727-23735. [CrossRef]

52. Gao, M.; Su, H.; Lin, Y.; Ling, X.; Li, S.; Qin, A.; Tang, B.Z. Photoactivatable Aggregation-Induced Emission Probes for Lipid Droplets-Specific Live Cell Imaging. Chem. Sci. 2017, 8, 1763-1768. [CrossRef] [PubMed]

53. Kang, M.; Gu, X.; Kwok, R.T.K.; Leung, C.W.T.; Lam, J.W.Y.; Li, F.; Tang, B.Z. A Near-Infrared AIEgen for Specific Imaging of Lipid Droplets. Chem. Commun. 2016, 52, 5957-5960. [CrossRef] [PubMed]

54. Wang, D.; Su, H.; Kwok, R.T.K.; Shan, G.; Leung, A.C.S.; Lee, M.M.S.; Sung, H.H.Y.; Williams, I.D.; Lam, J.W.Y.; Tang, B.Z. Facile Synthesis of Red/NIR AIE Luminogens with Simple Structures, Bright Emissions, and High Photostabilities, and Their Applications for Specific Imaging of Lipid Droplets and Image-Guided Photodynamic Therapy. Adv. Funct. Mater. 2017, 27, 1704039. [CrossRef]

55. Zheng, Z.; Zhang, T.; Liu, H.; Chen, Y.; Kwok, R.T.K.; Ma, C.; Zhang, P.; Sung, H.H.Y.; Williams, I.D.; Lam, J.W.Y.; et al. Bright Near-Infrared Aggregation-Induced Emission Luminogens with Strong Two-Photon Absorption, Excellent Organelle Specificity, and Efficient Photodynamic Therapy Potential. ACS Nano 2018, 12, 8145-8159. [CrossRef] [PubMed]

56. Guo, R.; Yin, J.; Ma, Y.; Li, G.; Wang, Q.; Lin, W. A Novel NIR Probe for Detection of Viscosity in Cellular Lipid Droplets, Zebra Fishes and Living Mice. Sensor. Actuators B-Chem. 2018, 271, 321-328. [CrossRef]

57. Thermo Fisher Scientific, LipidTOX Neutral Lipid Stain. Available online: https://www.thermofisher.com/ order/catalog/product/H34475 (accessed on 27 July 2018).

58. Fujimoto, T.; Ohsaki, Y.; Cheng, J.; Suzuki, M.; Shinohara, Y. Lipid Droplets: A Classic Organelle with New Outfits. Histochem. Cell. Biol. 2008, 130, 263-279. [CrossRef] [PubMed]

59. Jacquier, N.; Choudhary, V.; Mari, M.; Toulmay, A.; Reggiori, F.; Schneiter, R. Lipid Droplets Are Functionally Connected to the Endoplasmic Reticulum in Saccharomyces Cerevisiae. J. Cell. Sci. 2011, 124, 2424-2437. [CrossRef] [PubMed]

60. Layerenza, J.P.; González, P.; García de Bravo, M.M.; Polo, M.P.; Sisti, M.S.; Ves-Losada, A. Nuclear Lipid Droplets: A Novel Nuclear Domain. BBA-Mol. Cell Biol. Lipids 2013, 1831, 327-340. [CrossRef] [PubMed]

61. Nevo-Yassaf, I.; Lovelle, M.; Nahmias, Y.; Hirschberg, K.; Sklan, E.H. Live Cell Imaging and Analysis of Lipid Droplets Biogenesis in Hepatatis C Virus Infected Cells. Methods 2017, 127, 30-36. [CrossRef] [PubMed]

62. Tuohetahuntila, M.; Molenaar, M.R.; Spee, B.; Brouwers, J.F.; Wubbolts, R.; Houweling, M.; Yan, C.; Du, H.; VanderVen, B.C.; Vaandrager, A.B.; et al. Lysosome-Mediated Degradation of a Distinct Pool of Lipid Droplets during Hepatic Stellate Cell Activation. J. Biol. Chem. 2017, 292, 12436-12448. [CrossRef] [PubMed]

63. Wang, J.; Guo, X.; Li, L.; Qiu, H.; Zhang, Z.; Wang, Y.; Sun, G. Application of the Fluorescent Dye BODIPY in the Study of Lipid Dynamics of the Rice Blast Fungus Magnaporthe Oryzae. Molecules 2018, 23, 1594. [CrossRef] [PubMed]

64. Knight, M.; Braverman, J.; Asfaha, K.; Gronert, K.; Stanley, S. Lipid Droplet Formation in Mycobacterium Tuberculosis Infected Macrophages Requires IFN- $\gamma / \mathrm{HIF}-1 \alpha$ Signaling and Supports Host Defense. PLOS Pathog. 2018, 14, e1006874. [CrossRef] [PubMed]

65. Masedunskas, A.; Chen, Y.; Stussman, R.; Weigert, R.; Mather, I.H.; Nusrat, A. Kinetics of Milk Lipid Droplet Transport, Growth, and Secretion Revealed by Intravital Imaging: Lipid Droplet Release Is Intermittently Stimulated by Oxytocin. MBoC 2017, 28, 935-946. [CrossRef] [PubMed] 
66. Schnitzler, J.G.; Moens, S.J.B.; Tiessens, F.; Bakker, G.J.; Dallinga-Thie, G.M.; Groen, A.K.; Nieuwdorp, M.; Stroes, E.S.G.; Kroon, J. Nile Red Quantifier: A Novel and Quantitative Tool to Study Lipid Accumulation in Patient-Derived Circulating Monocytes Using Confocal Microscopy. J. Lipid. Res. 2017, 58, 2210-2219. [CrossRef] [PubMed]

67. Held, P. Lipid Accumulation in HepG2 Cells Exposed to Free Fatty Acids. Available online: https://www. biotek.com/resources / application-notes/lipid-accumulation-in-hepg2-cells-exposed-to-free-fatty-acids / (accessed on 14 August 2017).

68. Helmchen, F.; Denk, W. Deep Tissue Two-Photon Microscopy. Nat. Methods 2005, 2, 932-940. [CrossRef] [PubMed]

69. Wei, L.; Hu, F.; Shen, Y.; Chen, Z.; Yu, Y.; Lin, C.-C.; Wang, M.C.; Min, W. Live-Cell Imaging of Alkyne-Tagged Small Biomolecules by Stimulated Raman Scattering. Nat. Methods 2014, 11, 410-412. [CrossRef] [PubMed]

2018 by the authors. Licensee MDPI, Basel, Switzerland. This article is an open access article distributed under the terms and conditions of the Creative Commons Attribution (CC BY) license (http://creativecommons.org/licenses/by/4.0/). 